\title{
Research on the Index System of Core of Economic Activity Analysis in Grid Enterprise Based on Hierarchy-Grey Relation Method
}

\author{
Shanshan Wu ${ }^{1, a^{*}}$, Lili Zhang ${ }^{2, b}$ and Xin Wang ${ }^{3, c}$ \\ ${ }^{1}$ State Grid Energy Research Institute, Beijing, China \\ ${ }^{2}$ State Grid Energy Research Institute, Beijing, China \\ ${ }^{3}$ North China Electric Power University, Beijing, China \\ a'wushanshan@sgeri.sgcc.com.cn, bzhanglili@sgeri.sgcc.com.cn, ${ }^{c} 18888848635 @ 163 . c o m$
}

Keywords: Grey relation method; Grid enterprise core analysis index system; Relation coefficient

\begin{abstract}
This paper analyzes the factors that influence the electricity market, puts forward the grey correlation method and constructs the core index system of the economic activity analysis of the power grid enterprises. The analysis result proves the effectiveness of the system.
\end{abstract}

\section{Introduction}

The selection of business indicators for core of economic activity analysis is based on the content system of economic activity analysis, and adopts scientific methods to retain the important information of economic activities at utmost, so as to simplify the analysis contents and highlight the key points. The grey relational analysis method is generally applied to the construction of the index system. This paper uses the combination of qualitative and quantitative methods to construct the economic activity analysis index system of power grid enterprise, this method not only makes up for the expert subjective selection alone index meaning and personal experience, subjective arbitrariness strong defects, but also overcome the objective screening method relying too much on index data, ignoring the index actual meanings

\section{Method Introduction}

The theory of grey relation analysis was put forward by Chinese Professor Deng Julong in the late 1970s and early 80s. It takes the "small sample" and "poor information" uncertain system with some known information and partial information as the research object, and extracts valuable information from known information, and forms the exact description of the operation rules of the system. The grey relational analysis method is equally applicable to the quantity of the sample and the law of the sample. This method is less amount of calculation, and does not appear to be inconsistent with the qualitative analysis results that mathematical statistics method (regression analysis, variance analysis, principal component analysis, etc.) are incomparable advantages.

Correlation degree represents the degree of association between two things. Grey relational analysis is a multivariate factor analysis technique for describing the strength, size and order of relationships among factors by calculating grey correlation degree. The basic idea of grey relational analysis is to judge whether the relationship is close according to the similarity degree of the geometric shape of the sequence curve. The closer the curve is, the greater the correlation between the corresponding sequences, and the smaller the vice versa. This method has been applied in the direction of fault diagnosis, prediction, evaluation and so on.

For the operation data of the grid enterprise, there are some problems, such as the shortage of sample size, the change of the statistical caliber and so on. The advantage of grey relational analysis is that it is also applicable to the number of samples and whether the samples are regular or not. Therefore, grey relational analysis can be used to screen indicators for economic activity analysis. 


\section{Construction Process}

In this paper, based on the combination of subjective and objective view, a method of constructing the core index system for the analysis of economic activities of power grid enterprises based on hierarchical grey relational degree is proposed. For the power grid enterprise, the main index of its economic benefit is the profit. The factors that affect profits include macro-economic and financial environment, power market environment, power grid operation, power grid development, production and marketing, business efficiency and personnel performance. The macroeconomic and financial environment includes GDP, economic structure, consumption, investment, import and export, consumer price, social financing scale, interest rate, exchange rate and so on. The electricity market environment includes electricity consumption, electricity consumption structure, generating capacity and power generation structure. Grid operation includes death toll, power grid event, equipment event, power supply reliability rate, power supply voltage qualification rate, etc. The development of grid includes grid investment, scale of production and technological transformation. Production and marketing include purchase of electricity, electricity, industry expansion, market share, state power market transaction power and line loss rate. Business benefits include revenues, costs, profits, assets and liabilities, etc. The staff performance includes all the labor productivity, the number of workers, the input of education and training, the investment in science and technology, the cost of research and development, etc. In this case, the nested association analysis method is suitable for hierarchical analysis to form a "association tree".

First, a comprehensive index system for economic activity analysis of power grid enterprises is established based on expert experience, that is to say, the main factors affecting the economic operation of power grid enterprises. In order to make the evaluation indexes comprehensively, objectively reflect the actual situation of the economic operation of the power grid enterprise, this report is based on the principle of building index system combined with the actual situation of power grid enterprises after several research and repeated demonstration, based on the thought of hierarchical classification, the establishment of economic activity subjective hierarchical analysis index system of power grid enterprises. The system includes primary and secondary indicators, and the primary index is to classify economic activity analysis, and select a core indicator for each category as proxy variables. The secondary index is mainly the refinement of the primary index, including the different aspects of the classification of primary indexes and some structural indicators. Primary indicators in this paper will be divided into macro economic and financial environment (GDP), the power demand (areas are all social power consumption), power supply (barracks area power generation), production and marketing (electricity), the management benefit (profit), power grid operation (Power supply reliability of urban network), power grid development (grid investment), new energy development (new energy battery online), staff performance (all-personnel labour productivity).

The calculation and the grey relational degree between the indexes are used to merge and delete the indexes. Reasonable index of economic activity analysis class classification need to meet two points, one is each category are related to the economic activity analysis, the various indicators are the core indicator of economic activity analysis and profit correlation. The second is that the various categories reflect different aspects of economic activity analysis, and the indicators in each category are not strongly correlated. To this end, the primary level index is selected according to grey correlation analysis. Calculation index of each class two correlation between proxy variables, if the index of a certain class poor correlation with profit and can think this index is not necessary in the economic activity analysis index, index of the class may be removed. If it has a strong correlation between two types of indicators, argues that these two types of primary indexes to reflect the economic activity analysis in the same ways, can be combined analysis, through the steps to ensure the rationality of the classification.

The grey relational degree of the secondary index is calculated, and the index of correlation between the primary index and the secondary index is eliminated. Because each class a primary index involves multiple secondary indexes, grey correlation analysis is required for secondary indexes, and redundant indicators are eliminated. By using the primary index as the benchmark, the grey comprehensive correlation degree of all secondary indexes and corresponding primary indexes is calculated, and the 
index of relative strength is retained. At the same time, in order to avoid the strong correlation between the selected indexes, the redundant indexes with strong correlation according to grey comprehensive correlations between the two indexes will been eliminated.

After the above steps, the final economic activity analysis index system is obtained. Application of grey incidence analysis established the index system of indicators at all levels, the correlation degree between the correlation degree of strong, related indexes both simplify the inspection standard, and make the information is not subject to heavy loss, as to reduce the workload of evaluation. Based on this, the core index system of scientific and rational hierarchical economic activity is established. The index system combines expert experience and statistical analysis results with both subjective analysis and objective analysis, and simplifies the analysis of redundant analysis, which makes the analysis of economic activities more focused.

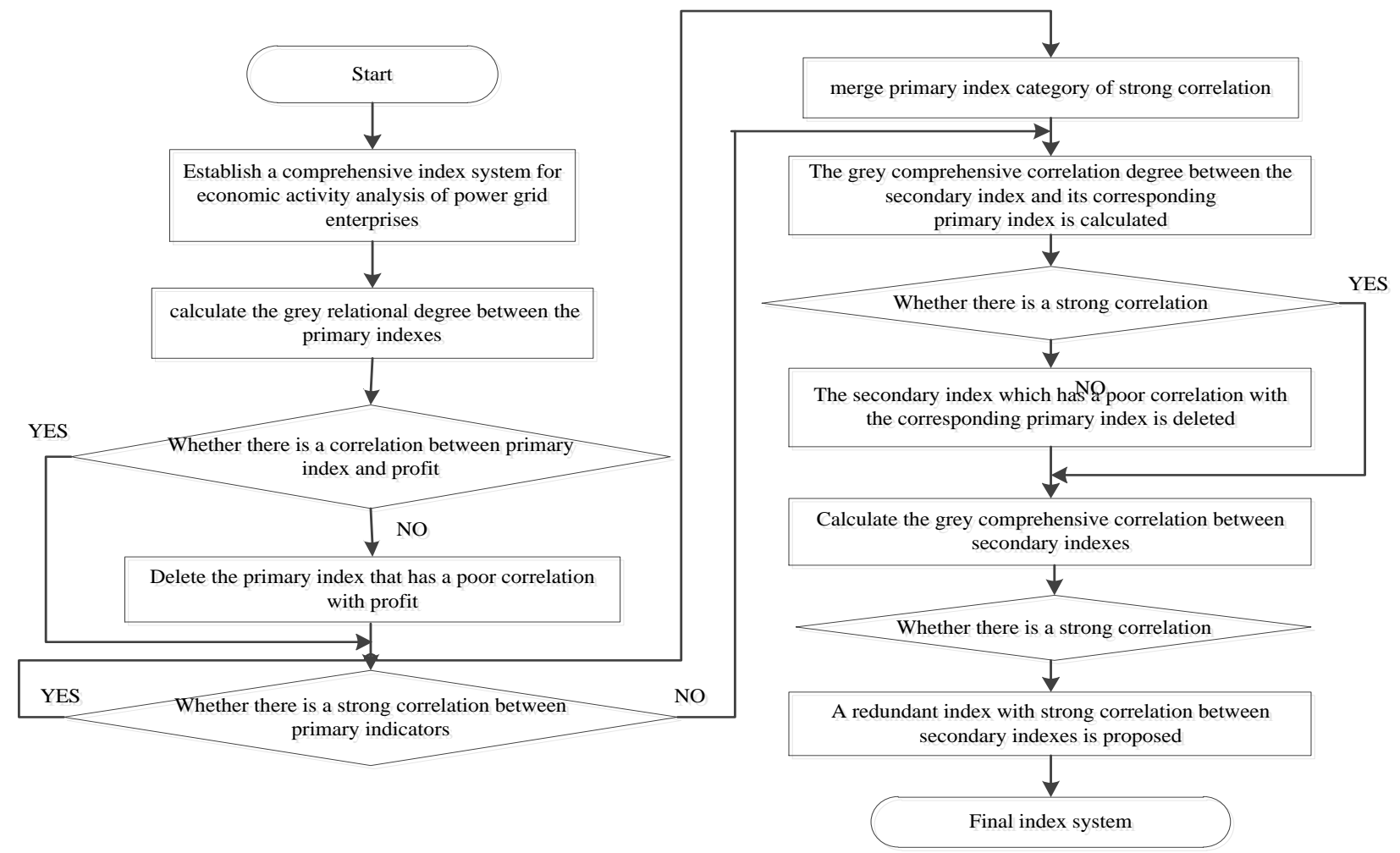

Figure 1. Construction process of economic activity analysis index system based on Grey Relational Analysis

\section{Construction results}

The grey absolute correlation coefficient and the grey relative correlation coefficient between the primary indexes are calculated, and the grey comprehensive correlation coefficient matrix is obtained by equal weight weighting, as shown in Table 2. It is known from the first line of the table, macroeconomic environment, the power demand, power supply, production and marketing, power grid operation, power grid development, new energy and staff performance are all related to the central indicators of business efficiency analysis(the grey comprehensive correlation coefficient is greater than 0.5 ). The grey correlation coefficient between the electricity demand and the electricity supply is 0.99 , indicating that the two have high correlation, which can be regarded as the same category, considering the combination of the two. Logically, due to the particularity of electric power products are difficult to store, result in power consumption and production of immediacy, and power rely mainly on self-sufficiency, and show a strong correlation between power supply and power demand. Therefore, it is reasonable to combine the two into the power market environment. The results of primary index classification based on grey correlation analysis are shown in Table 1. 
Table 1 Index grey comprehensive correlation coefficient matrix

\begin{tabular}{|c|c|c|c|c|c|c|c|c|c|}
\hline $\begin{array}{c}\text { Grey } \\
\text { comprehensiv } \\
\text { e relation } \\
\text { degree }\end{array}$ & $\begin{array}{c}\text { Managem } \\
\text { e-nt } \\
\text { benefit }\end{array}$ & $\begin{array}{c}\text { macro } \\
\text { economic } \\
\text { and } \\
\text { financial } \\
\text { environme } \\
\text { n-t }\end{array}$ & $\begin{array}{c}\text { power } \\
\text { demand }\end{array}$ & $\begin{array}{c}\text { power } \\
\text { supply }\end{array}$ & $\begin{array}{c}\text { productio } \\
\text { n and } \\
\text { marketing }\end{array}$ & $\begin{array}{c}\text { power } \\
\text { grid } \\
\text { operation }\end{array}$ & $\begin{array}{c}\text { power } \\
\text { grid } \\
\text { developm } \\
\text { e-nt }\end{array}$ & $\begin{array}{c}\text { new } \\
\text { energy } \\
\text { developm } \\
\text { e-nt }\end{array}$ & $\begin{array}{c}\text { staff } \\
\text { performan } \\
\text { c-e }\end{array}$ \\
\hline $\begin{array}{c}\text { management } \\
\text { benefit }\end{array}$ & 1.00 & 0.70 & 0.64 & 0.64 & 0.62 & 0.54 & 0.60 & 0.70 & 0.61 \\
\hline $\begin{array}{c}\text { macro } \\
\text { economic } \\
\text { and financial } \\
\text { environment }\end{array}$ & 1.00 & 0.61 & 0.61 & 0.58 & 0.54 & 0.60 & 0.69 & 0.58 \\
\hline $\begin{array}{c}\text { the power } \\
\text { demand }\end{array}$ & & 1.00 & 0.99 & 0.83 & 0.59 & 0.67 & 0.63 & 0.70 \\
\hline power supply & & & 1.00 & 0.82 & 0.58 & 0.67 & 0.63 & 0.70 \\
\hline $\begin{array}{c}\text { production } \\
\text { and marketing }\end{array}$ & & & & & 1.00 & 0.61 & 0.78 & 0.65 & 0.74 \\
\hline $\begin{array}{c}\text { power grid } \\
\text { operation }\end{array}$ & & & & & & 1.00 & 0.51 & 0.53 & 0.62 \\
\hline $\begin{array}{c}\text { power grid } \\
\text { development }\end{array}$ & & & & & & 1.00 & 0.73 & 0.53 \\
\hline $\begin{array}{c}\text { new energy } \\
\text { development }\end{array}$ & & & & & & & 1.00 & 0.58 \\
\hline $\begin{array}{c}\text { staff } \\
\text { performance }\end{array}$ & & & & & & & & 1.00 \\
\hline
\end{tabular}

Table 2 Classification results of primary indexes based on grey correlation analysis

\begin{tabular}{|c|c|c|c|}
\hline $\begin{array}{c}\text { Serial } \\
\text { numbers }\end{array}$ & category & index & $\begin{array}{c}\text { Grey comprehensive } \\
\text { relation with profit }\end{array}$ \\
\hline 1 & management benefit & Total profit & 1.00 \\
\hline 2 & $\begin{array}{c}\text { macro economic } \\
\text { and financial environment }\end{array}$ & GDP & 0.70 \\
\hline 3 & $\begin{array}{c}\text { Power market } \\
\text { environment }\end{array}$ & $\begin{array}{c}\text { Power consumption in the } \\
\text { whole society }\end{array}$ & 0.64 \\
\hline 4 & production and marketing & Electricity sale & 0.62 \\
\hline 5 & power grid operation & $\begin{array}{c}\text { Power supply reliability of } \\
\text { urban network }\end{array}$ & 0.54 \\
\hline 6 & power grid development & grid investment & 0.60 \\
\hline 7 & new energy development & new energy battery online & 0.70 \\
\hline 8 & staff performance & $\begin{array}{c}\text { all-personnel labour } \\
\text { productivity }\end{array}$ & 0.61 \\
\hline
\end{tabular}

Respectively by primary index as a benchmark to calculate the grey relation coefficient of secondary index and its corresponding level index, then correlation higher indexes, excluding index of correlation degree is low, so as to get the final secondary indicators.

Take the business benefit category as an example. Based on profit, the grey relational degree of all secondary indexes and profits in this category is calculated, and the results are shown in table 3. The two secondary indexes of grey correlation showed strong correlation between operating profit and net profit, and the grey comprehensive correlation was 0.95 , so the reproducibility index net profit was eliminated. 
Table 3 Grey relational degree of the operational benefit secondary index

\begin{tabular}{|c|c|c|c|c|}
\hline $\begin{array}{c}\text { Serial } \\
\text { numbers }\end{array}$ & $\begin{array}{l}\text { Operation benefit } \\
\text { secondary index }\end{array}$ & $\begin{array}{c}\text { Grey comprehensive } \\
\text { correlation degree } \\
\text { with total profit } \\
\end{array}$ & $\begin{array}{l}\text { Operation benefit } \\
\text { secondary index }\end{array}$ & $\begin{array}{c}\text { Grey comprehensive } \\
\text { correlation degree } \\
\text { with total profit } \\
\end{array}$ \\
\hline 1 & operating profit & 0.99 & Net operating income & 0.63 \\
\hline 2 & Net profit (elimination) & 0.91 & $\begin{array}{c}\text { Power plate one: } \\
\text { Power Grid } \\
\text { Investment } \\
\end{array}$ & 0.63 \\
\hline 3 & Market share & 0.82 & Net asset yield & 0.62 \\
\hline 4 & Main business profit & 0.76 & $\begin{array}{c}\text { Receivable electricity } \\
\text { balance of users }\end{array}$ & 0.62 \\
\hline 5 & $\begin{array}{l}\text { Main material market } \\
\text { price of power grid } \\
\text { equipment: angle steel } \\
\text { (reverse) }\end{array}$ & 0.73 & $\begin{array}{l}\text { Financial sector: total } \\
\text { assets }\end{array}$ & 0.62 \\
\hline 6 & $\begin{array}{c}\text { Industrial sector: total } \\
\text { profit }\end{array}$ & 0.73 & $\begin{array}{c}\text { Total assets: fixed } \\
\text { assets }\end{array}$ & 0.61 \\
\hline 7 & Total assets & 0.70 & $\begin{array}{c}\text { Power plate 1: } \\
\text { investment in fixed } \\
\text { assets }\end{array}$ & 0.60 \\
\hline 8 & $\begin{array}{l}\text { Industrial sector: } \\
\text { operating income }\end{array}$ & 0.67 & $\begin{array}{c}\text { Electric plate 1: the } \\
\text { length of the AC line } \\
(110 \text { thousand volts } \\
\text { and above })\end{array}$ & 0.60 \\
\hline 9 & $\begin{array}{c}\text { Financial sector: operating } \\
\text { income }\end{array}$ & 0.66 & $\begin{array}{c}\text { Main material market } \\
\text { price of power grid } \\
\text { equipment: aluminum } \\
\text { ingot (reverse) }\end{array}$ & 0.59 \\
\hline 10 & Total assets: mobile assets & 0.66 & Asset liability ratio & 0.59 \\
\hline 11 & $\begin{array}{l}\text { Main material market } \\
\text { price of power grid } \\
\text { equipment: copper } \\
\text { (reverse) }\end{array}$ & 0.66 & $\begin{array}{l}\text { Financial sector: rate } \\
\text { of return on net assets }\end{array}$ & 0.58 \\
\hline 12 & $\begin{array}{c}\text { Power plate 1: } \\
\text { transformer capacity (110 } \\
\text { thousand volts and above) }\end{array}$ & 0.65 & $\begin{array}{c}\text { Financial sector: asset } \\
\text { liability ratio }\end{array}$ & 0.56 \\
\hline 13 & $\begin{array}{l}\text { Financial sector: total } \\
\text { profits }\end{array}$ & 0.54 & $\begin{array}{c}\text { Turnover rate of } \\
\text { mobile assets }\end{array}$ & 0.56 \\
\hline
\end{tabular}

Based on hierarchical grey relation analysis, the core index system of economic activity analysis of power grid enterprises is shown in Table 4.A total of 50 primary and secondary indicators are included. 
Table 4 Core index system for economic activity analysis of power grid enterprises based on hierarchical grey relational analysis

\begin{tabular}{|c|c|c|c|c|}
\hline \begin{tabular}{|c|}
$\begin{array}{c}\text { Serial } \\
\text { numbers }\end{array}$ \\
\end{tabular} & $\begin{array}{l}\text { primary } \\
\text { indicators }\end{array}$ & secondary indicators & $\begin{array}{l}\text { primary } \\
\text { indicators }\end{array}$ & secondary indicators \\
\hline 1 & \multirow{6}{*}{$\begin{array}{l}\text { 1、 macro } \\
\text { economic and } \\
\text { financial } \\
\text { environment } \\
\text { (GDP) }\end{array}$} & Second industrial added value & \multirow{2}{*}{$\begin{array}{c}\text { 2、 Power } \\
\text { market } \\
\text { environment } \\
\text { (Power } \\
\text { consumption in } \\
\text { the whole } \\
\text { society) }\end{array}$} & $\begin{array}{l}\text { Operating regional } \\
\text { power generation }\end{array}$ \\
\hline 2 & & $\begin{array}{l}\text { Total retail sales of consumer } \\
\text { goods }\end{array}$ & & $\begin{array}{l}\text { The whole social } \\
\text { electricity } \\
\text { consumption in the } \\
\text { operation area: the } \\
\text { second industry }\end{array}$ \\
\hline 3 & & Third industry added value & \multirow{4}{*}{$\begin{array}{l}\text { 2、 Power } \\
\text { market } \\
\text { environment } \\
\quad \text { (Power } \\
\text { consumption in } \\
\text { the whole } \\
\text { society) }\end{array}$} & $\begin{array}{l}\text { Operating regional } \\
\text { power generation } \\
\text { equipment capacity: } \\
\text { Hydropower }\end{array}$ \\
\hline 4 & & SHIBOR:1 week & & $\begin{array}{l}\text { Power consumption in } \\
\text { the whole society: high } \\
\text { energy consumption } \\
\end{array}$ \\
\hline 5 & & Manufacturing investment & & $\begin{array}{l}\text { Operating regional } \\
\text { power generation } \\
\text { equipment capacity: } \\
\text { thermal power }\end{array}$ \\
\hline 6 & & CPI & & $\begin{array}{l}\text { The whole social } \\
\text { electricity } \\
\text { consumption in the } \\
\text { operation area: the } \\
\text { third industry }\end{array}$ \\
\hline 7 & \multirow{6}{*}{$\begin{array}{l}\text { 3. power grid } \\
\text { operation } \\
\text { (Power supply } \\
\text { reliability of } \\
\text { urban network) }\end{array}$} & \begin{tabular}{|c|}
$\begin{array}{c}\text { Qualified rate of } \\
\text { comprehensive power supply } \\
\text { voltage in city network }\end{array}$ \\
\end{tabular} & \multirow{6}{*}{$\begin{array}{l}\text { 4, power grid } \\
\text { development } \\
\text { (grid } \\
\text { investment) }\end{array}$} & $\begin{array}{l}\text { Investment in fixed } \\
\text { assets }\end{array}$ \\
\hline 8 & & $\begin{array}{l}\text { Power supply reliability of } \\
\text { agricultural network }\end{array}$ & & $\begin{array}{c}\text { Production scale of } \\
\text { this year: } 110 \\
\text { thousand volts and } \\
\text { above AC lines: UHV }\end{array}$ \\
\hline 9 & & $\begin{array}{c}\text { Qualified rate of } \\
\text { comprehensive power supply } \\
\text { voltage of agricultural network }\end{array}$ & & $\begin{array}{c}\text { New scale in this year: } \\
110 \text { thousand volts } \\
\text { and above power } \\
\text { capacity: UHV } \\
\end{array}$ \\
\hline 10 & & $\begin{array}{c}\text { Accumulative power grid } \\
\text { events in this year: 5-6 level } \\
\text { (reverse) }\end{array}$ & & $\begin{array}{l}\text { Production scale of } \\
\text { this year: } 110 \\
\text { thousand volts and } \\
\text { above AC lines: } 750 \\
\text { thousand volts } \\
\end{array}$ \\
\hline 11 & & Death (reversal) & & $\begin{array}{c}\text { The scale of } \\
\text { production in this year: } \\
110 \text { thousand volts } \\
\text { and above capacity: } \\
500 \text { thousand volts }\end{array}$ \\
\hline 12 & & Cumulative equipment events & & New scale in this year: \\
\hline
\end{tabular}




\begin{tabular}{|c|c|c|c|c|}
\hline & & of the year: 5-6 level (reverse) & & $\begin{array}{l}110 \text { thousand volts } \\
\text { and above capacity: } \\
220 \text { thousand volts }\end{array}$ \\
\hline 13 & & $\begin{array}{c}\text { Reliability index of } 110 \\
\text { thousand volts and above } \\
\text { overhead lines: coefficient of } \\
\text { availability }\end{array}$ & & $\begin{array}{l}\text { Approval of } 330 \\
\text { thousand volts and } \\
\text { above: line length }\end{array}$ \\
\hline 14 & \multirow{7}{*}{$\begin{array}{l}\text { 5. Production } \\
\text { and marketing } \\
\text { (electricity) }\end{array}$} & Business expansion (reversal) & \multirow{7}{*}{$\begin{array}{l}\text { 6、 the } \\
\text { management } \\
\text { benefit (profit) }\end{array}$} & operating profit \\
\hline 15 & & $\begin{array}{l}\text { Expansion of industry: } \\
\text { capacity: large industry }\end{array}$ & & Market share \\
\hline 16 & & $\begin{array}{l}\text { Electricity trading in the } \\
\text { national electricity market }\end{array}$ & & Main business profit \\
\hline 17 & & $\begin{array}{l}\text { Average net electricity price } \\
\text { (reverse) }\end{array}$ & & $\begin{array}{c}\text { Main material market } \\
\text { price of power grid } \\
\text { equipment: angle steel } \\
\text { (reverse) }\end{array}$ \\
\hline 18 & & $\begin{array}{l}\text { Volume reduction capacity } \\
\text { (reverse) cancellation }\end{array}$ & & \begin{tabular}{|c|} 
Industrial sector: total \\
profit
\end{tabular} \\
\hline 19 & & $\begin{array}{l}\text { Average transmission and } \\
\text { distribution price }\end{array}$ & & Total assets \\
\hline 20 & & Line loss rate (reverse) & & \\
\hline 21 & \multirow{6}{*}{$\begin{array}{l}\text { 7. new energy } \\
\text { development } \\
\text { (new energy } \\
\text { battery online) }\end{array}$} & $\begin{array}{l}\text { Power generation of new } \\
\text { energy }\end{array}$ & \multirow{6}{*}{$\begin{array}{c}\text { 8、 staff } \\
\text { performance } \\
\text { (all-personnel } \\
\quad \text { labour } \\
\text { productivity) }\end{array}$} & Number of workers \\
\hline 22 & & $\begin{array}{c}\text { New energy grid capacity: } \\
\text { biomass }\end{array}$ & & $\begin{array}{c}\text { Education and training } \\
\text { input }\end{array}$ \\
\hline 23 & & $\begin{array}{l}\text { Power generation of new } \\
\text { energy: wind power }\end{array}$ & & $\begin{array}{c}\text { Research and } \\
\text { development cost }\end{array}$ \\
\hline 24 & & Discarding rate (reversal) & & \\
\hline 25 & & Discarding rate (reversal) & & \\
\hline 26 & & New energy grid capacity & & \\
\hline 27 & & New energy approval capacity & & \\
\hline
\end{tabular}

\section{Evaluation of Results}

The primary selection index system can be obtained by qualitative analysis, and the principle is that the primary selection index can reflect the economic activities of the enterprise in an all-round way. Grey relational analysis, using quantitative analysis method to optimize index system, can make up for the deficiency of pure qualitative analysis. Through qualitative and quantitative analysis, we can establish relatively ideal index system of economic activity analysis.

This method mainly has the following problems:

The index screening method based on hierarchical grey correlation analysis is very important for the selection of primary indexes. Due to the primary index will serve as a secondary indicator screening benchmarks, and computes the secondary indicators and the corresponding indicators of grey correlation degree, so the choice of indicators will have important impact on the targets of the secondary screening. Therefore, it should be more prudent to choose a primary index, which can reflect the core content of the module as a primary index.

In the secondary index screening, although the index with strong correlation can be excluded from the secondary index, it is difficult to ensure that the selected indexes can represent different aspects of the category. There may be a selection of indicators that are all in the same category of indicators. The 
secondary index contains the structural indicators of total profit, Such as operating profit, main business profit and industrial sector profit. However, the three indexes are not related to each other, so the algorithm will retain all three. However, there may be redundancy in the profit side of the three indicators

\section{Conclusion}

This paper analysis the content of economic activities in grid enterprises, by hierarchy--grey relation method construct the economic activities of power grid enterprise core analysis index system, not only greatly simplifies the analysis of contents and index number, the economic activities of power grid enterprise core analysis index system, and has carried on the innovation in the method, by using gray correlation method at the level of expert subjective screening method relying solely on personal experience and objective screening method of excessive dependence on the data to find a balance between index. In the end, the paper gives the relevant explanation of this method, which lays the foundation for other research.

\section{References}

[1] Deng Ju-long. Introduction to grey system theory[J]. Journal of Grey Systems, 1989, 1 (1) : :1-24.

[2] Liu sifeng, Guo tianlist, Dang yaoguo. Grey system theory and its application[M]. Peking: Science Publishing Company, 1999: 46-59.

[3] Zeng Ming. Power enterprise plan management and its technical support system[M]. Peking: China Electric Power Press, 2001:204-228.

[4] Liu Yan. Analysis of economic activity of Shaanxi power company[J]. Shaanxi Electric Power, 2008, 36 (70).

[5] Geng Jinghua, Gao Qisheng, Zhang Siying. Community satisfaction evaluation system based on analytic hierarchy process and factor analysis[J]. Systems Engineering-Theory Methodology Application, 2007, 16 (6): 673-677.

[6] Geng Liyan, Zhang Tianwei, Zhao Peng,ect. The forecast of ls-svm rail freight volume based on grey correlation analysis[J]. Journal of Railway, 2012, 34 (3) :1-6. 